\title{
Towards a joint natural and cultural heritage management: modes of interaction
}

\section{Heleen van Londen}

University of Amsterdam, ACASA - Department of Archaeology, Amsterdam, the Netherlands

\begin{abstract}
Arguments for a joint natural and cultural heritage management practice follow a welltrodden path by now - we know what has to be done -, but not so much how to do it. The purpose of this article is to look at practical modes of interaction. What has been suggested so far? Although much has been gained through awareness-raising, the creation of common ground through comparing concepts, and integration within the planning processes, new practice seems to get stuck somewhere down the line. Difficulties relate to traditional thought-collectives, but also to power structures. In this article, I conclude that suggested actions are structured top-down and I propose four bottom-up strategies professionals in the workplace may want to consider to bridge the divide between both domains. As practice in heritage management systems is formed through the dynamic of processes (procedures, protocols, methods), organizations (management commitment, staffing, work routines) and professionals (skills and knowledge), modes of interaction should be focused on these pillars in the system. Bottom-up tactics may help decide professionals working within heritage management to engage in cross-overs. These range from full to partial integration, depending on the context of the task at hand.
\end{abstract}

Keywords: Heritage Management, Sustainable Landscape Development, Modes of Interaction, Bottom-up Approaches, System

\section{Introduction}

The reorganization of land to adapt to societal needs rapidly changes our environment. Change is an essential characteristic of landscapes and may occur slowly or swiftly, and is often dependent upon the circumstances of economic dynamics (Antrop 2003; 2006). This characteristic is highlighted in the European Landscape Convention (Florence Convention 2000). The consequence for heritage management is twofold. Firstly, historical landscapes should not be made into open air museums. This tends to offer a vision without deep timedepth, in which time appears frozen in a generic past, represented as a static and bounded cultural entity, property of history rather than of living tradition (Crang 1999). If the dynamics of change cease, the landscape will lose its vitality. The challenge therefore lies in the management of change. Landscapes are to be seen as Living Landscapes. Secondly, as the landscape is made up of what it is through interaction of nature and humans, then the focus for the management of change should be on that combination of the natural and the cultural. 
Although the European Landscape Convention (ELC) is now seen as the dominant EU framework for landscape management, the first recognition on an institutional level was the UNESCO World Heritage Convention (1992), where landscape was defined as "combined works of nature and man" (Article 1). In the operational guidelines for the implementation of the World Heritage Convention (2008), landscapes are divided into three categories (1) landscape deliberately designed and created by man; (2) organically evolved landscapes; (3) associative cultural landscapes. The ELC does not work with these categories; in it all landscape matters - beautiful, common or even run down - all require management of change. What needs managing is the change of the landscape character and quality (Clark et al. 2004, Fairclough \& Rippon 2002; Fairclough \& Van Londen 2010; Luginbuhl 2006). Once the landscape character has been identified, quality objectives are to be developed through by which the landscape can be protected, managed or developed. These policies are to be integrated into land use planning at all levels of governance. The ELC is committed to identifying and assessing landscapes through field research by professionals working with local communities. Local knowledge, community participation in citizen science driven projects, is valued because sustainable development, democracy and well-being belong to the principles of the ELC (Prieur 2006). Each landscape forms a mix of components and structures: types of territories, social perceptions and ever-changing natural, social and economic forces. For obtaining objectives and a recognized landscape character it is required to define the significance of landscape; to explain long-term change as a historic foundation for future changes, to recognize the interaction between nature and people and to make others aware that the present landscape is inherited from the past as a form of material culture, as heritage. Thirty-nine out forty-one EU member states (Council of Europe 2019) undersigned the ELC and have integrated the principles in national legislation and policy.

While European member states - as a result - have common policies for sustainable development, as illustrated by several conventions, nations have their own individual approach (Bloemers \& Van der Valk 2007). These national frameworks are thought to be best suited to address the challenges and characteristics of each country. Not only are landscapes diverse, policies too are manifold. What still seems to be lacking in practice is the integration of cultural heritage management and nature conservation. However, much is to be gained for instance regarding agricultural policy (CAP), flood protection (dikes, brook valleys), climate policies for $\mathrm{CO} 2$ reduction, and the energy transition. Some are typical for specific countries; others are challenges for all and will impact the landscape on a large scale. Farming, water management, climate and the exploitation of energy sources have a long history of structuring the landscape. The divide between the sectors is not only due to difficulties in uniting different traditions or thought-collectives, but also to power structures (Skoglund \& Svensson 2010), for instance the way safeguarding heritage is organized, how well the significance is recognized, the task perception of organizations and legislation frameworks. Arguments for a joint heritage management practice is a well-trodden path by now (among others Brown et al. 2005; Philips 2005; Harmon 2007; Renes 2013, 2018a) - we know what has to be done -, but not so much how to do it. The purpose of this article is to look at practical modes of interaction. What has been suggested so far? This article then proposes four basic strategies for specialists in the workplace wanting to bridge the divide between both domains. As practice in heritage management systems is formed through the dynamic of processes (procedures, protocols, methods), organizations (management commitment, staffing, work routines) and professionals (skills and knowledge), modes of interaction should be focused on these pillars in the system. 


\section{A solution to which problem?}

Summing up some of the challenges.

- Damages. Inadvertently, sectoral approaches to safeguarding heritage often leads to damage in another domain, such as flooding, mowing, deep-rooting species, clearing vegetation from monuments and such;

- Perception landscape significance. Recognition of equal importance of both domains is sometimes difficult to obtain. A good example is the Wadden Sea area, which is predominantly seen in practice as a Natural World Heritage Site. A special agenda was written for the aims of emancipation, researching and safeguarding cultural values in the area (Bazelmans 2009; Renes 2018);

- Legislation and permits. Legislation in the nature domain is much stricter than in cultural heritage management. Natura 2000 areas are protected natural habitats. Development in such areas is only permitted after proved major public interest and no alternatives exit. In the early stages of planning, it is much harder albeit impossible - to get a permit to develop in a Natura 2000 area, than it is to negatively impact protected cultural heritage, while both are essential for the landscape character. Legislation comes first and then landscape quality objectives second;

- Knowledge and skills. Integral (interdisciplinary) knowledge and skills are often lacking for proper understanding of both domains;

- Mission statements. Departments within organizations work separately. Often when individuals are motivated to work integrally, support from higher up may get in the way. Organizations rarely act outside their task description.

These challenges can easily be related to the three parts of the management system, so to people (perspective, knowledge and skills), to procedures (for instance legislation and permits) and organizations (mission statements).

A general accepted definition of Interdisciplinary Studies is "a process of answering a question, solving a problem, or addressing a topic that is too broad or complex to be dealt with adequately by a single discipline or profession." (Klein \& Newell 1997, cited by Fuchsman 2009, 71). A common vocabulary and other common ground help integration, leading to a more comprehensive perspective. These basic principles of interdisciplinarity are recognizable in policy frameworks, such as the ELC.

Actions belonging to interdisciplinarity revolve around integration, interacting, linking, focusing and blending, while transdisciplinarity aims for change through transcending, transgressing or transformating. In both cases, new types of disciplines are created. In contrast, in multidisciplinary frameworks disciplines remain unchanged. In such a context, new information is gained through juxtaposing, sequencing or coordinating (Klein 2010: 15-19). According to Kleins taxonomy, interdisciplinarity ranges between the complementing of disciplines to the transformation into hybrid forms, between partial and full integration. With it come degrees of collaborations and types of practice varying from broad to narrow, from methodological to theoretical, from bridge building to total restructuring of institutions and so forth. 


\section{Trends, approaches and guidelines so far}

The ELC recognizes the need for awareness-raising, training and education (people) as well as integrative planning policies and innovative tools (processes). Above all, the sectors need to understand each other. Emphasis is put on the exchange - and adaptation - of professional language, imagery, motivation and value systems (Pedroli \& Van Mansvelt 2006; Prieur 2006). Understanding lies at the very basis of any form of cooperation. When both sectors understand each other's priorities, they can find ways to work together, find common ground. Understanding relates not only to disciplinary heritage management practices, but also to the landscape itself. A model has been developed as one of the outputs of the Interreg Europe project, Planarch (PLANning and ARCHaeology 1999-2006), that places understanding of landscape at the core of a cyclical process of identification, evaluation, management and promotion (Williams 2010: 559).

Recent policy and research aimed at interdisciplinary approaches, illustrate trends and practical guidelines at least since 2000. The character ranges from professional concepts and language (Clark 2000) to understanding value systems (Hooimeijer et al. 2001; Dauvellier 2004), to best practices based on experience (Leitão et al. 2017), and to awareness-raising and incentives (Raap 2015; Bleumink \& Neefjes 2017), even to a new perception of heritage - as part of a paradigm shift -in which disciplinary boundaries are useless (Harrison 2015). Below, these trends and guidelines will be shortly examined.

\section{Professional concepts and language}

Kate Clark published an inventory of trends in European cultural heritage management at the start of the millennium, noting a development towards the use of broader concepts and the wider role of cultural heritage in society (Clark 2000). She participated in a specialist consultation group within the framework of the Forward Planning Project for the Cultural Heritage Committee (CC-PAT) that drafted a paper for the 5th European conference of Ministers responsible for the cultural heritage, on the theme "The cultural heritage and the challenge of globalization". The reported trends show a change in perception towards interdisciplinarity and democratization that parallels the ideas of the European Landscape Convention. It offers an overview of the shifts in professional concepts and language at the time that were implemented in policy and research from then on. The use of new terms are indicative of a landscape perspective dominance. Keywords relate to structures, (urban) areas and regions, to management skills and responsibilities that lie within the environmental sector (table 1).

Ashworth noted that the shift of focus from monument to landscape may very well count as paradigmatic, but still has safeguarding heritage - with intrinsic historic values - at its core motivation (Ashworth 2005). In his publication, he emphasizes the present day and future consumption of places. The more substantial paradigm shift, according to Ashworth, is the recognition that heritage is a present day construction and activity, which resonates with Holtorf, Fairclough and Harrison (Holtorf \& Fairclough 2013, Harrison 2015, Van Londen 2016). This new heritage perspective leads away from landscape management, towards a broader role in societal issues; the latter a trend already described by Clark some twenty years ago (Clark 2000). 


\begin{tabular}{|c|c|c|}
\hline & FROM & TO \\
\hline \multirow[t]{3}{*}{ Definition of Heritage } & Monuments & Landscapes \\
\hline & Buildings & Urban areas \\
\hline & Sites & Historic environment/cultural heritage \\
\hline \multirow{2}{*}{$\begin{array}{l}\text { Role of Heritage in } \\
\text { Society }\end{array}$} & National unity & Respect for cultural diversity \\
\hline & $\begin{array}{l}\text { Generate revenue from } \\
\text { visitors }\end{array}$ & Wider economic benefits Social benefits \\
\hline \multirow[t]{2}{*}{ Decisions } & State & Region/locality \\
\hline & Authoritarian & Democratisation Participation \\
\hline \multirow[t]{3}{*}{ Professionals } & Experts & Facilitators \\
\hline & $\begin{array}{l}\text { Single discipline (e.g., } \\
\text { buildings, archaeology) }\end{array}$ & Multiskilled professionals \\
\hline & Historical knowledge & Management skills \\
\hline \multirow[t]{5}{*}{ Significance } & Old & Industrial heritage; post-war buildings \\
\hline & Aesthetic & Commemorative value \\
\hline & National importance & Local distinctiveness \\
\hline & Monocultural & Values of different cultures \\
\hline & Narrow range of values & Wide range of values \\
\hline Interpretation & Expert led & Community led \\
\hline \multirow[t]{2}{*}{ Responsibilities } & State led & Communities/the market/private sector \\
\hline & Heritage sector & Environmental sector \\
\hline \multirow[t]{4}{*}{ Management Practices } & Designation & Characterization \\
\hline & Separate conservation & Integrated conservation \\
\hline & Site based & More strategic \\
\hline & Technical research & Philosophical research \\
\hline
\end{tabular}

Table 1. Trends in European heritage management at the turn of the millennium (Clark 2000: 112). The concepts show a shift in heritage management perception towards landscape, environment, interdisciplinarity and democratisation.

\section{Value systems and spatial quality}

Land use planners contributed to the understanding of values and interests that come together in the field of spatial planning. For instance, in The Netherlands, land use planners and landscape architects developed a pragmatic approach for the rather vague term 'spatial quality' which has become a central aim in Dutch policy (Hooimeijer et al. 2001; Raad 2011, 13). The term is closely related to the idea of landscape character and the quality objectives of the ELC. Spatial quality has been defined as the sum of user value, perceived value and future value (table 2 after Dauvellier 2004, 27; Dauvellier et al. 2014: 225). These are explained by example. When buying a house, the house must facilitate the activities of the people living in it (user value), the house needs have the right atmosphere (perceived value) and it must be adjustable to future use, not too expensive to maintain and has to keep its market value (future value) (Dauvellier et al. 2014: 225). These values are equally applicable to the landscape scale. They were brought together in a matrix relating to the interests of economy, society, ecology and culture, facilitating the analysis of local situations, identifying the spatial quality of the area. 


\begin{tabular}{|c|c|c|c|c|}
\hline & $\begin{array}{l}\text { ECONOMIC } \\
\text { INTEREST }\end{array}$ & $\begin{array}{l}\text { INTEREST TO } \\
\text { SOCIETY }\end{array}$ & $\begin{array}{l}\text { ECOLOGICAL } \\
\text { INTEREST }\end{array}$ & $\begin{array}{l}\text { CULTURAL } \\
\text { INTEREST }\end{array}$ \\
\hline User Value & $\begin{array}{l}\text { Allocational } \\
\text { efficiency } \\
\text { Accessibility } \\
\text { Incentives } \\
\text { Combined use }\end{array}$ & $\begin{array}{l}\text { Access } \\
\text { Equitable distribution } \\
\text { Input of diverging } \\
\text { interests } \\
\text { Options for } \\
\text { stakeholder groups }\end{array}$ & $\begin{array}{l}\text { External safety } \\
\text { No negative impacts } \\
\text { Water system in } \\
\text { equilibrium } \\
\text { Green networks }\end{array}$ & $\begin{array}{l}\text { Freedom of } \\
\text { choice } \\
\text { Cultural } \\
\text { diversity }\end{array}$ \\
\hline $\begin{array}{l}\text { Perceived } \\
\text { value }\end{array}$ & $\begin{array}{l}\text { Image } \\
\text { Value for money } \\
\text { Attractiveness }\end{array}$ & $\begin{array}{l}\text { Equality } \\
\text { Engagement } \\
\text { Social safety }\end{array}$ & $\begin{array}{l}\text { Tranquility and space } \\
\text { Natural beauty } \\
\text { Healthy habitat }\end{array}$ & $\begin{array}{l}\text { Individuality } \\
\text { Coherence } \\
\text { Cultural beauty } \\
\text { Environment } \\
\text { full of contrast }\end{array}$ \\
\hline Future Value & $\begin{array}{l}\text { Stability and } \\
\text { flexibility } \\
\text { Agglomeration } \\
\text { Clustered attractions }\end{array}$ & $\begin{array}{l}\text { Everyone on board } \\
\text { Widespread support in } \\
\text { society }\end{array}$ & $\begin{array}{l}\text { Ecological stocks } \\
\text { Sustainable ecosystems }\end{array}$ & $\begin{array}{l}\text { Heritage } \\
\text { Integration } \\
\text { Cultural renewal } \\
\text { Identity }\end{array}$ \\
\hline
\end{tabular}

Table 2. Matrix of the interpretations of 'spatial quality' as it is used in interactive plan making: characteristics to be specified per area (Bloemers et al 2010: 28 after Dauvellier 2004: 27). The matrix combines different values as interests of economy, society, ecology and cultural heritage to facilitate inclusive spatial design without actually integrating the disciplines.

For cultural heritage experts the above planning concepts were especially of interest, as they offered room for the sustainable development of archaeological-historical landscape. Emphasis was placed on cultural heritage protection through development (Bloemers et al. 2010), not as much on the integration of cultural and natural heritage. Nonetheless, interdisciplinarity was sought after with other disciplines studying the past and outside the field of cultural heritage. Interdisciplinarity in the domain of cultural history was labelled internal integration, while the interaction with planning, politicians and the public was called external integration (Van der Valk 2010: 32-33). The biography of landscape, a form of storytelling and action research were put forward as unifying concepts to facilitate these integrations (Bloemers 2010, 11-13). Through storytelling, the long-term history of places can be told, emphasizing landscape transformations, using information from various disciplines (Kolen et al. 2015: 2018; Van Beek et al. 2008: 179-184). Action research is a methodology aimed at solving real-life problems. Researchers and participants in particular (policy) practices generate new knowledge by joint communication processes that lead to social action (Greenwood \& Levin 2007,149, Bloemers $2010,9)$. As such, it is a form of strategic research, directly influencing practice. In the United Kingdom, Historic Landscape Characterization was developed, a GIS based analytical method for landscape classification covering every inch of land (Clark et al. 2004). 
In the first decennium, the use of cultural history in land use planning was not restricted to the Netherlands, but more widespread and referred to as the policy of cultural planning. However, in the Netherlands it became part of national policy whereas in other European countries it was more applied on a local level and project based (Belvedere Memorandum 1999; Jansen et al. 2013: 9). Today, still much attention is given to cultural planning as illustrated by the initiative of Heriland, an international graduate school for cultural heritage and planning of European Landscapes (VU 2019). Within this case, focus lies on future uses of the past.

Pedroli and Van Mansvelt, with a background in landscape studies, presented unifying models and concepts for sustainable development as part of the European Landscape Convention framework (Pedroli \& Van Mansvelt 2006: 132-3). The authors state that motivation - needs - are the driving force to link scientific disciplines. They refer to Maslow's triangle, combining peoples need to natures need, i.e. the earth limited resources. Various disciplines are ordered through it, explaining how each domain does contribute to sustainability.

The ordering in both approaches (Dauvellier et al. 2014 and Pedroli \& Van Mansvelt 2006), i.e from planning and landscape studies, are multidisciplinary, aiming to be inclusive of other domains. Certainly, the planners matrix is a hands-on tool for combining the most important sets of information from the disciplines. Recently, a comparable assessment matrix was designed for Natuurmonumenten (Natural Monuments Society), a Dutch NGO for nature conservation, to include heritage management in nature reserves (Purmer 2018). The author offers a tool to test the effects of proposed development on both natural and cultural landscape qualities in the targeted area.

\section{Best practices: lessons learnt}

Using best practices from pilot projects is a well-known strategy to obtain grounded ideas and experiences in new fields. The International Council on Monuments and Sites (ICOMOS) and the International Union for Conservation of Nature (IUCN) jointly published the outcomes of the Connecting Practice project. The project aims to

\section{"explore, learn and create new methods of recognition and support for the interconnected character of the natural, cultural and social value of highly significant land and seascapes and affiliated biocultural practices" (Leitão et al. 2017: 3).}

The recommendations from this project are best practices drawn from pilot projects of World Heritage Sites. The deeper motivation is to develop a uniform methodology for the management of both cultural and ecological heritage. The work has resulted in a first reference document, which serves as a guide for future policies. Some of the lessons learnt are the following:

- Promote dialogue between national institutions dealing with nature and culture;

- Strengthen the capacity of staff and experts within advisory bodies who contribute to their work on the interrelationships between nature and culture;

- Promote best practice, including carrying out fieldwork that could contribute to the development of detailed outreach;

- Develop a joint guide on the management of world natural and cultural heritage (currently there are separate guides). 
Clearly, the targeted practice envisions a heritage management dealing with institutions, professionals and processes at once.

\section{Awareness-raising and practical guidelines}

Some of the concepts and best practices mentioned above have been translated into recent policy guidelines. For instance, the Netherlands incorporated heritage as an inseparable part of the use of space and spatial developments (RCE 2011). The program Living Landscape focuses on area-specific approaches, interlinking the interests in the fields of economy, ecology and heritage. A dialogue has started regarding agricultural policy, water management and new infrastructure for the energy transition.

Practical guidelines can be found as the result of cooperation between government bodies, such as cultural heritage agencies and those focused on particular land use or redevelopment (Raap 2015; Bleumink \& Neefjes 2017). The main function seems to be awareness-raising in the other domain, explaining heritage values and benefits and showing good examples. Among the aspects advocated are the following arguments:

- Landscape and heritage enhance quality and individuality;

- Heritage offers inspiration and points of departure for contemporary planning;

- Attractive landscape and regional identity are important economic factors;

- Knowledge of landscape and heritage helps to understand the functioning of brook systems;

- Ecological values are often linked to historical land use and water management;

- Public support and citizen participation;

- Water-awareness and (youth) education;

- Folk tales;

- Landscape and heritage as a unifying theme in spatial assignments;

- Brooks as a connection between city and countryside;

- Multiple heritage;

- Care and diligence (legislation).

These arguments to pay attention to and even more so, actively engage with - in this case with cultural heritage - range from rather soft values - trying to seduce- to the harder motivations, meaning legislation. The practical guidelines seem targeted at the higher institutional management level, addressing task perceptions, using the carrot and the stick method.

\section{Bottom up: Four strategies to interact}

The selection of trends, approaches and guidelines that advocate cross-overs span a period of some twenty years. In general, they are structured according to a top-down approach. However, bottom-up modes of interaction may speed up the implementation process for cross-overs. These may influence organizations, management and protocols from within. 
Four strategies can be deduced for experts working within set frames of legislation and institutional divides. The proposed tactics differ in their increase or decrease of actual sectoral integration and the effort that has to be made for a jointly approach. This choice depends on the context of the task at hand, the degree of integration sought after and the difficulty of reaching a common approach. The terms used for interdisciplinary activities, like integrating, interacting, linking, focusing and blending are all apt descriptions in this context.

\section{Integrated approach}

The integrated approach can be best illustrated by the heritage management of historical gardens. The garden design, pathways, views, water sculptures and vegetation form an entity. These aspects can be studied separately, but to truly understand, safeguard, and experience the gardens, all elements should be treated as interdependent. Firstly, research is needed to appreciate how all elements are interwoven in the garden design and further developments, secondly a management plan has to be designed to safeguard all aspects for future use.

Such an approach may be applied to any landscape, whenever a meaningful cultural and/or natural landscape interrelation is chosen for safeguarding. The classification of the World Heritage Convention (2008) into three categories (1) landscape deliberately designed and created by man; (2) organically evolved landscapes; (3) associative cultural landscapes, may offer a relevant framework.

Integration in this case means interdisciplinary work within projects where data, methods, measurements and public engagement get to be integrated. Examples are for instance, the biography of landscape, a narrative of landscape transformation (Kolen et al. 2015: 2018; Van Beek et al. 2008: 179-184), or Historic Landscape Characterization (HLC), a GIS database (Clark et al. 2004). These types of activities, when selected, will result in strategic cooperation, networks and new shared knowledge in the workplace.

\section{Layered approach}

With layering as a tactic, various disciplines and interests are listed together like chapters in a report. The planners matrix is such an example (see table 2). Here, economy, society, ecology and cultural heritage are brought together without wanting to merge any of the domains. The matrix helps to explicate a wide spectrum of interest to facilitate inclusion of all aspects belonging to spatial quality. The format is multidisciplinary, using sequencing, each layer complementing the other. Another example of layering can be found in Environmental Impact Assessments (EIA). Here, negative or positive effects for quite a number of aspects must be thought over before changing the landscape. By specifically paying attention to these disciplines, a good solution can be found for creating new sustainable landscapes or finding mitigation measurements. A project can go through different organizational units, collecting information for each interest. This approach will offer opportunities to learn and to get acquainted with concepts and experts in other sectors.

\section{Hitchbiking}

Hitchhiking is a tactic where an opportunity created by the other discipline is used. For 
instance, cultural heritage sites located within a Natura 2000 area can hitchhike on the protective measurements that follow the legal framework for ecology, which is much stronger. Other examples for instance are archaeological sites located in drinking water reserves or on military domains used fortraining. The Dutch Ministry of Defence issued a policy in 2016 allowing for co-use of military areas. The main function of the areas is military use, all other functions are subordinate to that. However, these functions are most often not in conflict with each other and therefore the aims are to maintain and protect the natural and cultural heritage landscape values and offer opportunities for nature development. Nature and landscape legislation and regulations impose their own restrictions on the use of sites. The Ministry of Defence commits to faithfully implementing these regulations, but does not have a stricter policy than necessary (Ministerie van Defensie 2011).

In these cases areas are protected, but not mainly for the safeguarding of heritage. To apply such strategy, knowledge of other disciplines and relevant legal frameworks are required. It also means cooperation between different departments within organizations on management levels. Hitchhiking has the potential to influence task perceptions of organizations.

\section{Copying/adopting good practice from the other discipline}

The least complicated strategy is copying a good practice from another discipline. The methods described above all require some sort of collaboration, while copying means introducing something new while firmly staying in your comfort zone. This tactic can be focused on concepts, processes, as well as methods, maps or instruments and depends on the specific context for it to be effective. Adopting a good practice means being informed of those practices in other disciplines. Its success often depends on an individual with a broad background. Through adopting good practice protocols, methods and procedures can be influenced. Purmer studied the role of heritage in nature reserves owned by Natuurmonumenten (Natural Monuments Society) (Purmer 2018). His research questions relate to how the various concepts of nature, heritage and landscape are of use for the organisation (Purmer 2018: 449). Borrowing concepts from other disciplines is common in academic practice (Klein 2017: 25). If the influence of the borrowed method in practice is moderate the relation is classified as auxiliary relationship. However, this can grow into a supplementary relationship when the impact increases.

\section{Conclusion}

The last twenty years the culture/nature divide has been widely debated in heritage management policies. A large majority by now is in favor of a joint approach, basically motivated by the complexity of landscapes as well as the larger challenges facing society, like climate change, the energy transition and such. Although much has been gained through awareness-raising, the creation of common ground through concepts, and within planning processes, new practice seems to get stuck somewhere down the line. Since heritage management systems are structured through institutions, procedures and professionals, it may be helpful to address professionals in the workplace. Bottom-up tactics may help decide professionals working within heritage management to engage in cross-overs. These range from full integration to partial integration, depending on the context of the task at hand. Full integration is by far the most complex way to go. Successful full integration - in the end - will lead to a transformed new practice, leaving behind the sectoral approaches as 
outdated solutions. As sectors are institutionalised conflicts may very well arise. Layering - a multidisciplinary approach - may offer a quick and pragmatic solution to an inclusive practice. Here, disciplines remain relevant by themselves. Hitchhiking can be extremely effective as illustrated by the Dutch defense policy of co-use. However, finding an influential partner to hitch a ride may require some savyness. Finally, borrowing concepts, methods or procedures from the other sector may help overcome some practical issues.

\section{References}

Antrop, M., 2003. Landscape change and the urbanization process in Europe. Landscape and Urban Planning 67, 9-26.

Antrop, M., 2006. Sustainable landscapes: contradiction, fiction or utopia? Landscape and Urban Planning 75, 87-197.

Ashworth, G. J., 2005. Heritage and the consumption of places., in: R. VAn Der LAarse, (ed.), Bezeten van vroeger: erfgoed identiteit en musealisering, 193 - 206.

Bazelmans, J., 2009. Geschiedenis, herinnering en beleving: naar een cultuurbistorische en sociaalwetenschappelijke onderzoeksagenda voor het Waddengebied. De Waddenacademie.

Beek, R. Van, Bloemers, J.H.F, Keunen, L., Londen, H. van \& Kolen, J., 2008. The Netherlands, in: G. Fairclough \& Grau Møller, P., (eds). Landscape as Heritage. The Management and Protection of Landscape in Europe, a summary by the Cost A 27 Project LANDMARKS. Bern: Geographica Bernensia 79, 177-203.

Belvedere, 1999. The Belvedere Memorandum. A policy document examining the relationship between cultural history and spatial planning, The Hague.

Bleumink, H. \& Neefjes, J., 2017. Handboek Beken en Erfgoed. Beeklandschappen met karakter. Stichting Toegepast Onderzoek. Waterbeheer in samenwerking met de Rijksdienst voor het Cultureel Erfgoed. Bloemers, J.H.F., 2010. The Cultural Landscape and Heritage Paradox. Protection and Development of the Dutch Archaeological-Historical Landscape and its European dimension, Abstract, in: J. H. F. Bloemers, H. Kars, A. van der Valk, \& M. Wijnen (eds), The cultural landscape \& heritage paradox: protection and development of the Dutch archaeological-historical landscape and its European dimension. (Landscape \& heritage series). Amsterdam: Amsterdam University Press, 11-13.

Bloemers, T., Kars, H., Van der Valk, A. \& Wijnen, M. (eds). 2010. The cultural landscape \& heritage paradox: protection and development of the Dutch archaeological-historical landscape and its European dimension. (Landscape \& heritage series). Amsterdam: Amsterdam University Press. Bloemers, J.H.F., van der Valk, A., 2007. The Oer IJ: A metropolitan wetland on Amsterdam's doorstep. The archaeological-historical landscape as inspiration for spatial planning, in: B.Pedroli, A. van Doorn, G. De Blust (eds), Europe's Living Landscapes. Essays exploring our identity in the countryside. Zeist, 161-176.

Brown, J., Mitchell, N. \& Beresford, M., 2005. Protected landscapes: a conservation approach that links nature, culture and community, in: J. Brown, N. MitCHELL \& M. BERESFORD (eds), The protected landscape approach linking nature, culture and community. Gland: IUCN, 3-18.

CLARK, K., 2000. From regulation to participation: cultural heritage, sustainable development and citizenship, in: CouncIl of Europe, Forward Planning, the function of cultural heritage in a changing Europe, 103-113.

Clark, J., Darlington, J., Fairclough, G., 2004. Using Historic Landscape Characterisation. English Heritage: London.

Crang, M. ,1999. Globalization as Conceived, Perceived and Lived Spaces. Theory, Culture 
and Society 16 (1), 167-177.

Council Of Europe, 2000. European Landscape Convention, Florence.

Dauveluier, P., 2004. Ruimtelijke kwaliteit als recept. ROM Maandblad voor Ruimtelijke Ontwikkeling 3, 26-29.

Dauvellier, P., Puylaert, H., De Jonge, J. 2014. Ruimtelijke Kwaliteit: De Werkbankmethode, in: W. Simons \& D. van Dorp (eds), Praktijkgericht onderzoek in Ruimtelijke Planvorming, 225-233.

Fairclough, G. \& Rippon, S., (eds), 2002. Europe's cultural landscape: archaeologists and the management of changes. Brussels: EAC Occasional Paper no. 2.

Fairclough, G., \& Van Londen, H. (2010). Changing landscapes of archaeology and heritage, in: T. Bloemers, H. Kars, A. van Der VAlK, \& M. Wijnen (eds), The cultural landscape \& heritage paradox: protection and development of the Dutch archaeological-historical landscape and its European dimension. (Landscape \& heritage series). Amsterdam: Amsterdam University Press, 653-669.

FuCHSMAN, K. , 2009. Rethinking integration in interdisciplinary studies. Issues in Integrative Studies 27 (2009): 70-85.

Greenwood, D.J. And Levin, M., 2007. Introduction to action research Social research for social change. Sage Publications, Thousand Oaks.

Harmon, D., 2007. A bridge over the chasm: Finding ways to achieve integrated natural and cultural heritage conservation. International Journal of Heritage Studies 13 (4-5), 380-392.

Harrison, R., 2015. Beyond "Natural" and "Cultural" Heritage: Toward an Ontological Politics of Heritage in the Age of Anthropocene. Heritage \& Society, Vol. 8, no. 1, May, 2015, 24-42.

Holtorf, C. \& Fairclough, G., 2013. The New Heritage and re-shapings of the past, in: A. GonzÁlez-Ruibal (ed.), Reclaiming Archaeology: Beyond the Tropes of Modernity. Abingdon and New York: Routledge, 197-210.

Hoomeijer, P., Kroon, H. \& Luttik, J., 2001. Kwaliteit in meervoud; conceptualisering en operationalisering van ruimtelijke kwaliteit voor meervoudig ruimtegebruik. Gouda: Habiform.

KleIN, J.T., 2010. A taxonomy of interdisciplinarity. , in: R. Frodeman (ed.), The Oxford Handbook of Interdisciplinarity, Oxford: Oxford University Press, 15-30.

KLEIN, J.T., 2017. Typologies of Interdisciplinarity: The Boundary Work of Definition, in: R. Frodeman, (ed.), The Oxford Handbook of Interdisciplinarity (2nd ed.), Online Publication Date: Mar 2017. Accessed January 2018. Oxford: Oxford University Press, 21-35.

Kolen J. C. A., Hermans, R. \& Renes, H., (eds), 2015. Landscape Biographies. Geographical, Historical and Archaeological Perspectives on the Production and Transmission of Landscapes. Amsterdam: Amsterdam University Press.

Kolen, J. C. A., Renes, J. \& Bosma, K., 2018. The landscape biography approach to landscape characterisation - Dutch perspectives, in: G. Fairclough, I. Sarlöv-Herlin \& C. Swanwick (eds), Routledge Handbook of Landscape Character Assessment - Current approaches to characterisation and assessment. Abingdon: Routledge, 168-184.

Janssen, J., Luiten, E., Renes, H., Rouwendal, J., 2013. Oude sporen in een nieunve eeuw: de uitdaging na Belvedere, Rijksdienst voor het Cultureel Erfgoed: Amersfoort.

Leitão, L., Bourdin, G., Badman, T. \& Wigboldus, L., 2017. Connecting Practice Phase II: Final Report. Project Report. ICOMOS/IUCN.

Londen, H. van, 2016. Archaeological Heritage Education and the Making of Regional Identities, in C. Boxtel, M. Grever \& S. KleIN (eds), Sensitive Pasts. Questioning Heritage in Education. Berghahn Books, 153-170.

Luginbuhl, Y., 2006. Landscape and individual and social well-being, preamble to the 
convention, in: Council of Europe, Landscape and sustainable development: challenges of the European Landscape Convention, 15. https://rm.coe.int/16804895e6, 99-118.

Pedroli, B., \& van Mansvelt, J.D., 2006. Landscape and awareness-raising, training and education, Article 6 of the convention, in: Council of Europe, Landscape and sustainable development: challenges of the European Landscape Convention, 15. https:// rm.coe.int/16804895e6, 119-142.

Phillips, A., 2005. Landscape as a meeting ground: Category V protected landscapes/ seascapes and World Heritage cultural landscapes, in: J. Brown, N. Mitchell \& M. BERESFORD (eds), The protected landscape approach linking nature, culture and community. Gland: IUCN, 19-35.

Prieur, M., 2006. Landscape and social, economic, cultural and ecological approaches, preamble to the convention, in: CouncIL OF Europe, Landscape and sustainable development: challenges of the European Landscape Convention, 15. https:/ / rm.coe.int/16804895e6, 31-54.

Purmer, D. M., 2018. Het landschap bewaard: Natuur en erfgoed bij Natuurmonumenten. Uitgeverij Verloren.

Svensson, E., Skoglund, P., 2017. Discourses of nature conservation and heritage management in the past, present and future. Discussing heritage and sustainable development from Swedish experiences. European Journal of Archaeology 3 (3), 368-385.

RAAD, V., 2011. Verkenning 'Ruimtelijke kwaliteit', Den Haag.

RAap, E., 2015. Visie Erfgoed en Ruimte, programmalijn Levend Landschap. Amersfoort: Rijksdienst voor het Cultureel Erfgoed.

Renes, J., 2013. Natuur en landschap op zoek naar een nieuw verbond, printed paper 12.06.2013.

Renes, J., 2018a. New nature in old landscapes - Some Dutch examples of the relation between history, heritage, and ecological restoration. Environmental Values 27 (4), 351-375.

Renes, J., 2018b. The Wadden Sea as a cultural landscape - History, heritage, management, in: L. Egberts \& M. Schroor (eds), Waddenland outstanding. History, landscape and cultural heritage in the Wadden Sea region. Amsterdam: Amsterdam University Press, 45-63.

UNESCO, 2008. Operational Guidelines for the Implementation of the World Heritage Convention.

Van Der Valk, A., 2010. Planning the past. Lessons to be learned from 'Protecting and Developing the Dutch Archaeological-Historical Landscape' (PDL/BBO), in: T. Bloemers, H. Kars, A. Van der Valk, M. Wijnen (eds), The Cultural Landscape \& Heritage Paradox. Protection and Development of the Dutch Archaeological-Historical Landscape and its European Dimension. Amsterdam: Amsterdam University Press, 21-51.

Williams, J., 2010. The Planarch experience, in: J.H.F. Bloemers, H. Kars, A. van der Valk, \& M. WIJNEN (eds), The cultural landscape \& heritage paradox: protection and development of the Dutch archaeological-historical landscape and its European dimension. (Landscape \& heritage series). Amsterdam: Amsterdam University Press, 559-564. 
